\title{
Spor Bilimleri Fakültesi Öğrencilerinde Yaşam Doyumu ve Umutsuzluğun Madde Kullanma Eğilimine Etkisinin Araștırılması
}

\author{
Hülya Çolak ${ }^{1}$ \\ Doç. Dr. Hakan ÜNAL ${ }^{2 *}$
}

Geliş tarihi: 05.02.2020

Kabul tarihi: 28.03.2020

\section{Atuf bilgisi: \\ IBAD Sosyal Bilimler Dergisi \\ Sayı: $7 \quad$ Sayfa: $344-357$}

Yıl: 2020 Dönem: Yaz

This article was checked by Turnitin. Similarity Index $6 \%$

Bu makalede araştırma ve yayın etiğine uyulmuștur.

${ }^{1}$ Muğla Sttkı Koçman Üniversitesi, Türkiye, hulya_hsc@hotmail.com, ORCID ID 0000-0003-2867-6937

${ }^{2}$ Muğla Sttkı Koçman Üniversitesi, Türkiye,,hakan@mu.edu.tr, ORCID ID 0000-0002-4570-6205

* Sorumlu yazar
ÖZ

$\mathrm{Bu}$ çalışma, Spor Bilimleri Fakültesi öğrencilerinin, yaşam doyumları ve umutsuzluk durumlarının madde kullanma eğilimi üzerindeki etkilerini incelemek amacı ile yapılmıştır. Araştırma grubunu, Gazi Üniversitesi Spor Bilimleri Fakültesinde öğrenim gören 220'si kadın 202'si erkek olmak üzere 422 öğrenci oluşturmaktadır. Araştırmada veri toplama aracı olarak Madde Kullanma Eğilimi Ölçeği, Yaşam Doyum Ölçeği ve Beck Umutsuzluk Ölçeği kullanılmıștır. Araştırmada elde edilen veriler SPSS for Windows 22.0 programı kullanılarak analiz edilmiştir. Verilerin değerlendirilmesinde tanımlayıcı istatistiksel yöntemleri olarak sayı, yüzde, ortalama, standart sapma kullanılmıştır. İki bağımsız grup arasında niceliksel sürekli verilerin karşılaştırılmasında t-testi, ikiden fazla bağımsız grup arasında niceliksel sürekli verilerin karşılaştırılmasında Tek yönlü (Oneway) Anova testi kullanılmıştır. Anova testi sonrasında farklılıkları belirlemek üzere tamamlayıcı post-hoc analizi olarak Scheffe testi kullanılmıştır. Araştırmanın sürekli değişkenleri arasında pearson korelasyon ve regresyon analizi uygulanmıştır. Sonuç olarak; Spor Bilimleri Fakültesi öğrencilerinin yaşam doyumunun madde kullanma eğilimini azalttığı ve umutsuzluğun madde kullanma eğilimini artırdığı sonucuna varılmıştır. Bu artışta umutsuzluk alt boyutları arasında yer alan motivasyon kaybının etkili olduğu belirlenmiștir.

Anahtar Kelimeler: Madde Kullanma, Umutsuzluk, Yașam Doyumu, Üniversite Öğrencisi 
Investigation of the Effects of Life Satisfaction and Hopelessness on Substance Abuse Tendency in Sports Science Faculty Students

Hülya Çolak ${ }^{1}$

Assoc. Prof. Dr. Hakan Ünal ${ }^{2 *}$

First received: 05.02 .2020

Accepted: 28.03.2020

\section{Citation:}

IBAD Journal of Social Sciences

Issue: 7

Pages: 344-357

Year: 2020

Session: Summer

This article was checked by Turnitin. Similarity Index $6 \%$

\footnotetext{
${ }^{1}$ Muğla Sitki Kocman University, Turkey, hulya_hsc@hotmail.com,

ORCID ID 0000-0003-2867-6937
}

${ }^{2}$ Muğla Sitki Kocman University, Turkey, hakan@mu.edu.tr

ORCID ID 0000-0002-4570-6205

* Corresponding Author

\begin{abstract}
This study was conducted to examine the effects of life satisfaction and hopelessness on the substance abuse tendency of the Faculty of Sports Sciences Faculty students. The research group consists of 422 students, 220 of which are females and 202 of which are males. In the research, the Item Use Tendency Scale, Life Satisfaction Scale, and Beck Hopelessness Scale were used as data collection tools. The data obtained in the study were analyzed using SPSS for Windows 22.0 program. Number, percentage, average and standard deviation were used as descriptive statistical methods in the evaluation of the data. The t-test was used to compare quantitative continuous data between two independent groups and the One way Anova test was used to compare quantitative continuous data between more than two independent groups. Scheffe test was used as a complementary post-hoc analysis to determine the differences after the Anova test. Pearson correlation and regression analysis were used among the continuous variables of the study. As a result; It has been concluded that the life satisfaction of students of the faculty of sports sciences decreases the tendency to use substances and hopelessness increases the tendency to use substances. It was determined that the loss of motivation, which is among the sub-dimensions of hopelessness, was effective in this increase.
\end{abstract}

Keywords: Substance Use, Hopelessness, Life Satisfaction, University Student 


\section{GİRIŞ}

Bağımlılık eğilimi olan kişilik özelliklerini tanımlamak karmaşık olmasına rağmen, bu yatkınlık tipi bir takım ortak özellikler barındırmaktadır. Bu özelliklerin tayin edilmesinde, merkezi sinir sistemi, kalıtımsal yapı, kendilik gelişimi, bireyin içinde yaşadığı aile, arkadaşlar, çevre ve bu çevrede sahip olduğu roller büyük önem taşımaktadır (Beyazyürek ve Şatır, 2000). Birçok birey, belirli miktarda yasal veya yasadışı ya da reçeteli bir şekilde ulaşım sağladıkları uyuşturucu maddeleri kısa süreli etkileri için kullanma ihtiyacı hisseder. Ancak bazı bireylerde aşırı kullanım da görülmektedir. Aşırı kullanım görülen bireylerde, neden bağımlılık düzeyinde kullanıldığına araştırmacılar iki temel teori ile açıklık getirmeye çalışmışlardır. Bu modelin ilki biyolojik modeldir. Biyolojik model; bağımlılığa bireyde bulunan genetik yapıdaki bozukluklar, bireyin metabolizma ve biyokimyasının sebep olduğundan bahsederken, ikinci model olan öğrenme modeli bağımlılığın günah veya bir hastalık olmadığını savunmaktadır (Wade ve Tavris, 1999). Son zamanlarda yapılan çalışmaların birçoğunun uyuşturucu madde kullanan bireylerin kişilik özelliklerini belirlemeye yönelik olduğu görülmektedir. Maddenin kötüye kullanımına sebep olarak gösterilebilecek kişilik özellikleri belirlenmeye çalışılarak uyuşturucu madde bağılılarındaki kişilik bozukluğu sorununun genel yapıya göre yüksek oranda gözlemlendiği belirtilmiştir (Gulkan, 1994). Madde bağımlılığını etkileyen temel faktörlerden birisi umutsuzluk faktörü olarak karşımıza çıkmaktadır.

Umutsuzluk, güven duygusundan yoksunluk olarak tanımlanabilir (Rideout ve Montemuro, 1986). Umutsuzluğun bir diğer tanımı ise bireyin kendisine ve geleceğine yönelik duygularının negatifliği olarak belirtilmiştir (McLaughlin, Miller ve Warwick, 1996). Karşıt beklentileri ifade eden umut ve umutsuzluk kavramı bireylerin ilerleyen yaşantılarındaki hedeflerinin gerçekleşme olasıllı̆ıına karşı oluşan beklentilerdir. Hedeflere ulaşılabileceği düşüncesi umudu, hedeflere ulaşmada başarısızlık yaşanabileceği düşüncesi ise umutsuzluğu anlatmaktadır (Dilbaz ve Seber, 1993). Umutsuzluğun sebepleri arasında, çeşitli etkenlere bağlı olarak bireyin etkinliklerin uzun süre kısıtlanmasını ve bunun sonucunda ortaya çıkan yalnızlık, beden sağlığının kötüleşmesi, Uzun süreli stres, kendini bırakmak, soyut değerlere ve/veya Allah'a olan inancı kaybetmek, belirtileri arasında ise, kötümser içerikli konuşmalar, dilde olumsuz ifadeler, edilgenlik, konuşmada azalma, duyguların ifadesinin azalması, inisiyatif kullanma eksikliği, dış uyaranlara karşı tepkilerin azalması, kendisiyle konuşan kişiye ilgisizlik, umursamaz ve aldırmaz tavırlar, iştahta azalma, uyku saatlerinde artma ya da azalma, kişisel bakıma özen göstermeme, sosyal ortamlardan kaçma bulunmaktadır (Üngüren ve Ehtiyar, 2009).Umutsuzluk duygusunun yoğun olarak çocuklarda, intihara teşebbüs eden ergenlerde, yabancilaşma ve moral bozukluğu yaşan bireylerde görüldügü belirtilmektedir.Insanların yaşantıları olumlu duygular kadar olumsuz ve zorlayıcı duyguları da barındırmaktadır. Olumlu duygular, mutlulukları, hazları, sevindiren olayları içerirken; olumsuz duygular, mutsuzluk ve acı veren olayları, üzüntü yaşanılan anları içerir (Akyüz ve Ünlü, 2014). İnsanların öznel bir şekilde algıladıkları bu olumlu veya olumsuz duyguları pozitif ya da negatif olarak değerlendirme sonucu yaşam doyumu kavramını ifade etmektedir. Bireylerin hedef olarak belirlediği olayları gerçekleştirme derecesi yaşam doyumunu belirlemektedir (Aşan ve Erenler, 2008). Bireyin yaşam doyumunun fazla olması için istekleri ile gerçekleştirdikleri arasındaki uyumsuzluk düzeyinin düşük olması gerektiği kabul edilmektedir (Diener, Oishi ve Lucas, 2003).

Yaşam doyumu filozofların da tartışma konusu olmuş ancak bu konuda bir görüş birliği sağlanamamıştır (Sirgy vd., 2006). Yaşam doyumu bireyin yaşamındaki gerçekleştirmek istediği en önemli hedeflerden bir tanesi olduğu belirtilmektedir. Bu sebeple de bilimsel olarak incelenmesi gerekli bir konu olduğu açıktır. Yaşam doyumu ile bireyin psikopatolojik yönleri yerine güçlü yönlerini tanımlamak ve geliştirmek mümkün olmaktadır (Seligman, 2007). Geçmişten günümüze kadar yaşam doyumunun bağlı olduğu sebepler ve hangi özellikte bireylerin daha mutlu olduğu araştırılmıştır. Yaşam doyumu ile ilişkili olması beklenen ve araştırmalara konu olan değişkenler arasında, yaş, cinsiyet, gelir, çalışma, ırk, evlilik ve aile, eğitim, din, sosyal etkileşim bulunmaktadır. $\mathrm{Bu}$ değişkenlere ek olarak yaşamsal etkinlikler, aktiviteler, kişilik, biyolojik etkenler gibi değişkenlerin de yaşam doyum düzeyine etkisi olduğu bilinmektedir (Eroğlu, 2011).

Kişilik özellikleri ve psikolojik tanılar ile madde kullanımı arasında ilişki olduğu belirtilmiştir (Dalack vd., 1993). Yapılan çalışmaların birçoğunda madde kullanımı ile psikolojik faktörler arasında bir ilişki 
olduğu görülmüştür. Sutherland'a göre insan davranışları, sıkıntı ve keder duyduğu durumlara mümkün olduğunca uzak, haz ve zevk aldığ 1 durumlara ise yakın olmaya çalışan bir sistem şeklindedir (Dolu, 2010).

Son zamanlarda, gelişmiş ülkelerden ergenlere odaklanan çeşitli araştırmalar, spor katılımının alkol almak, sigara içmek veya yasa dışı uyuşturucu kullanımına karşı koruyucu olarak kabul edilebileceğini öne sürmüştür (Pate ve diğ., 2000). Fiziksel aktivite, pozitif sağlı sonuçları, fonksiyonel kapasite, pozitif ruh hali ve genel refah arasında kanıtlanmış pozitif bir bağlantı vardır (Plante ve Rodin, 1990). Bununla birlikte, mevcut literatürde spor katılımı ve madde kullanımı konusunda önemli bir boşluk vardır ve bu nedenle böyle bir ilişkinin var olduğuna dair kesin bir kanıt yoktur (Lisha ve Sussman, 2010).

Madde kullanımına başlamada psikolojik faktörlerin etkisi oldukça yüksektir. Son yıllarda özellikle ergen nüfusundaki madde kullanımı artışı göz önüne alındığında madde kullanma eğilimi yüksek olan bireylerin özellikleri dikkate alınarak, madde kullanımına başlamadan önce alınabilecek tedbirler için öneriler geliştirilmesinin amaçlandığı çalışmada problem cümlesi, Spor Bilimleri Fakültesi öğrencilerinin umutsuzluk ve yaşam doyumu durumlarının madde kullanma eğilimine etkisi var mıdır? olarak belirlenmiştir.

\section{GEREÇ VE YÖNTEM}

\section{Araştırmanın Grubu}

Araştırmamızın evrenini Ankara İli Gazi Üniversitesi’nde öğrenim gören öğrenciler oluşturmaktadır, örneklemini ise Gazi Üniversitesi Spor Bilimleri Fakültesinde öğrenim görmekte olan öğrenciler oluşturmaktadır. Basit rasgele örnekleme yöntemi uygulanarak yapılmış olan çalışmada, hata payı (alfa) $=0.005$, hoşgörü miktarı $(\mathrm{d})=0.05$ ve kitledeki kişi sayısı $(\mathrm{N})=935$ (Gazi Üniversitesi Spor Bilimleri Fakültesi Öğrenci sayısı) olarak alındığında, örneklem çapı (n) $=420$ olarak belirlenmiş ve 220'si kadın 202'si erkek toplamda 422 öğrenciye ulaşılarak ölçekler uygulanmıştır.

Katılımcılara Madde Kullanma Eğilimi, Yaşam Doyumu, Depresyon, Umutsuzluk ve Algılanan Sosyal Destek ölçekleri uygulanmıştır. Katılımcılar, anket uygulamalarına gönüllü olarak katılmışlardır.

\section{Veri Toplama Araçları}

Madde Kullanma Eğilimi Ölçeği; Orijinal adı Substance Abuse Proclivity Scale (SAP) olan ölçek 36 sorudan oluşmaktadır. 16 ve üzeri puan alan kişinin madde kullanma eğilimi taşıdığı bildirilmiştir. Ters puanlanan maddeler şunlardır: 9, 12, 13, 19, 24, 25, 26, 29, 35. Mac Andrew bu çalışmada madde bağımlıs1, alkol bağımlıs1, psikiyatrik hasta ve normal grup olarak toplam 650 erkek deneğe MacAndrew Alkolizm Ölçeği (MAC) ve Madde Kullanma Eğilimi Ölçeği (MKEÖ) uygulanmıştır. Test tekrar test güvenilirliği aynı gruba 60 gün arayla iki kez test verilerek saptanmıştır. MKEÖ' nün madde bağımlılığına eğilimi belirlemede yararlı olacağı saptanmış olup ülkemizde sayıları gittikçe artan madde bağımlılığı kliniklerine tedavi amacıyla yatırılan hastaların yanı sıra kullanma eğilimi olan genç nüfusu belirlemede yardımc1 olabileceği düşünülmektedir (MacAndrew, 1989; Ceyhun vd., 2001; Ceyhun, Oral, 2003). Bu araştırmada madde kullanım eğilimi ölçeğinin güvenirliği Cronbach's Alpha $=0,847$ olarak yüksek bulunmuştur.

Yaşam Doyumu Ölçeği (YDÖ); Yaşam doyumunu ölçmek amaciyla geliştirilen bu ölçek 'hiç katılmıyorum'dan, 'tamamen katılıyorum'a kadar değişen cevaplar içeren, 5 maddeli bir ölçektir (Diener vd.,1985). Her bir maddeden alınan puanlar 1 ile 7, toplam puan ise 1-35 arasında değişebilmektedir. Ölçekten alınan puan yükseldikçe yaşam doyumunun yükseldiğine işaret eder. Ölçeğin Türkçe geçerlik, güvenirlik çalışması Köker (1991) ve Yetim (1993) tarafından yapılmıştır. Yetim'in çalışmasında ölçeğin Cronbach alfa değeri 0.86 olarak bildirilmiştir (Yetim, 1993). Bu araştırmada yaşam doyumu ölçeğinin güvenirliği Cronbach's Alpha $=0,819$ olarak yüksek bulunmuştur.

Umutsuzluk Ölçeği; 11 doğru, 9 yanlış anahtar yanıtı olan 20 doğru-yanlış önermeden oluşmuştur. Ölçek kendi kendine yanıtlanmaktadır. Anahtara uyumlu her yanıt için 1 puan, uyumsuz her yanıt için ise 0 puan verilmektedir. Elde edilen aritmetik toplam "Umutsuzluk puanı" olarak kabul edilmiştir. Puanların 
olası değişkenliği 0 ile 20 arasındadır. 1., 6., 13., 15., 19., önermeler gelecek ile ilgili duyguları, 2., 3., 9., 11., 12., 16., 17., 20., önermeler motivasyon kaybını, 4., 7., 8., 14., 18., önermelerde gelecek ile ilgili beklentileri ifade etmektedir. Önermeler duygusal, motivasyonel ve bilişsel etmenlerden oluşmaktadır (Beck vd., 1974). Bu araştırmada umutsuzluk ölçeğinin güvenirliği Cronbach's Alpha $=0,789$ olarak yüksek bulunmuştur.

\section{Verilerin İstatistiksel Analizi}

Araştırmada elde edilen veriler SPSS (Statistical Package for Social Sciences) for Windows 22.0 programı kullanılarak analiz edilmiştir. Araştırma değişkenlerinin analizinde büyük sayılar kanununa göre örneklem sayısı $(n=422)$ yüksek olduğundan parametrik yöntemler kullanılmıştır. Verilerin değerlendirilmesinde tanımlayıcı istatistiksel yöntemleri olarak sayı, yüzde, ortalama, standart sapma kullanılmıştır. İki bağımsız grup arasında niceliksel sürekli verilerin karşılaştııılmasında t-testi, ikiden fazla bağımsız grup arasında niceliksel sürekli verilerin karşılaştırılmasında Tek yönlü (Oneway) Anova testi kullanılmıştır. Anova testi sonrasında farklılıkları belirlemek üzere tamamlayıcı post-hoc analizi olarak Scheffe testi kullanılmıştır. Araştırmanın sürekli değişkenleri arasında pearson korelasyon ve regresyon analizi uygulanmıştır.

\section{Araştırmanın Sınırlılıkları}

Araştırma Gazi Üniversitesi Spor Bilimleri Fakültesi’nde örgün bir biçimde öğrenim gören ve araştırmaya katılmayı kabul eden 422 öğrenci ile sınırlıdır. Araştırma bu çalışmada uygulanan anketlerde bulunan sorulara verilen cevaplarla sınırlıdır. Bu çalışma Gazi Üniversitesi'nde öğrenim gören öğrencilerine ve Yükseköğretim Kurumu'na bağlı diğer tüm üniversite öğrencilerine uygulanabilmesi açısından sınırlılıklara sahiptir.

\section{BULGULAR}

Tablo 1. Madde Kullanma Eğilimi Puan Ortalaması

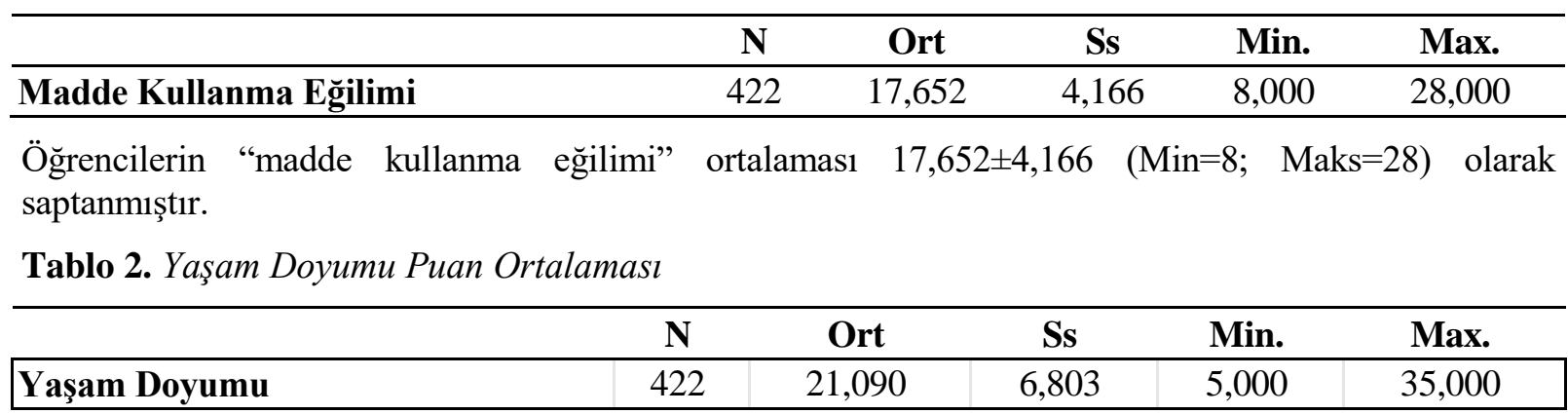

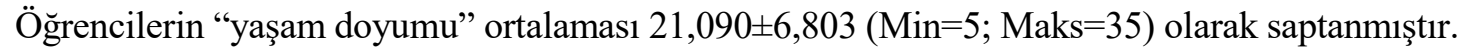

Tablo 3. Umutsuzluk Puan Ortalamaları

\begin{tabular}{l|c|c|c|c|c}
\hline & N & Ort & Ss & Min. & Max. \\
\hline Umutsuzluk & 422 & 6,716 & 4,069 & 1,000 & 18,000 \\
\hline Gelecekle İlgili Duygular & 422 & 1,280 & 1,508 & 0,000 & 5,000 \\
\hline Motivasyon Kaybı & 422 & 2,851 & 1,784 & 0,000 & 8,000 \\
\hline Gelecekle İlgili Beklentiler & 422 & 2,033 & 1,434 & 0,000 & 5,000 \\
\hline
\end{tabular}

Öğrencilerin "umutsuzluk" ortalaması 6,716 $\pm 4,069$ (Min=1; Maks=18), "gelecekle ilgili duygular"

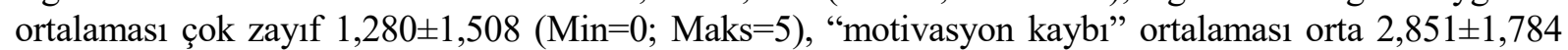
(Min=0; Maks=8), "gelecekle ilgili beklentiler" ortalaması zayıf 2,033 $\pm 1,434$ (Min=0; Maks=5), olarak saptanmıştır. 
Spor Bilimleri Fakültesi Öğrencilerinde Yaşam Doyumu ve Umutsuzluğun Madde Kullanma Eğilimine Etkisinin Araştırılması

Tablo 4. Psikolojik Parametreler İle Madde Kullanma Eğilimi Arasında Korelasyon Analizi

\begin{tabular}{l|cc}
\hline \multirow{2}{*}{ Yaşam Doyumu } & \multicolumn{2}{c}{ Madde Kullanma Ĕğilimi } \\
\hline \multirow{2}{*}{ Umutsuzluk } & $\mathrm{R}$ & -0.148 \\
\cline { 2 - 3 } & $\mathrm{P}$ & 0.002 \\
\cline { 2 - 3 } Gelecekle İlgili Duygular & $\mathrm{R}$ & 0,306 \\
\cline { 2 - 3 } & $\mathrm{P}$ & 0,000 \\
\cline { 2 - 3 } \multirow{2}{*}{ Motivasyon Kaybı } & $\mathrm{R}$ & 0,213 \\
\hline \multirow{2}{*}{ Gelecekle İlgili Beklentiler } & $\mathrm{P}$ & 0,000 \\
\cline { 2 - 3 } & $\mathrm{R}$ & 0,392 \\
\hline & $\mathrm{P}$ & 0,000 \\
\cline { 2 - 3 } & $\mathrm{P}$ & 0,153 \\
\hline
\end{tabular}

Madde kullanma eğilimi ile yaşam doyumu, umutsuzluk, gelecekle ilgili duygular, motivasyon kaybı ve gelecekle ilgili beklentiler arasında korelasyon analizleri incelendiğinde;

- Yaşam doyumu ile madde kullanma eğilimi arasında negatif yönlü düşük düzeyde,

- Umutsuzluk ile madde kullanma eğilimi arasında pozitif yönlü düşük düzeyde,

- Gelecekle ilgili duygular ile madde kullanma eğilimi arasında pozitif yönlü düşük düzeyde,

- Motivasyon kaybı ile madde kullanma eğilimi arasında pozitif yönlü orta düzeyde,

- Gelecekle ilgili beklentiler ile madde kullanma eğilimi arasında pozitif yönlü düşük düzeyde anlamlı ilişki bulunmaktadır.

Tablo 5. Yaşam Doyumunun Madde Kullanma Eğilimi Üzerine Etkisi

\begin{tabular}{cllllllll}
\hline Bağımlı Değişken & Bağımsız Değişken & $\mathbf{B}$ & $\mathbf{T}$ & $\mathbf{p}$ & $\mathbf{F}$ & Model $(\mathbf{p})$ & $\mathbf{R}^{\mathbf{2}}$ \\
\hline \multirow{2}{*}{ Madde Kullanma Eğilimi } & Sabit & 19,559 & 29,865 & 0,000 & 29,360 & 0,002 & \multirow{2}{*}{0,019} \\
\cline { 2 - 6 } & Yaşam Doyumu & $-0,090$ & $-3,059$ & 0,002 & & & \\
\hline
\end{tabular}

Yaşam doyumu ile madde kullanma eğilimi arasındaki neden sonuç ilişkisini belirlemek üzere yapılan regresyon analizi anlamlı bulunmuştur $(\mathrm{F}=9,360 ; \mathrm{p}=0,002<0.05)$. Madde kullanma eğilimi düzeyindeki toplam değişim \%1.9 oranında yaşam doyumu tarafindan açıklanmaktadır $\left(R^{2}=0,019\right)$. Yaşam doyumunun madde kullanma eğilimi düzeyini azalttığı düşünülmektedir. $(\beta=-0,090)$

Tablo 6. Umutsuzluğun Madde Kullanma Ĕ̈ilimi Üzerine Etkisi

\begin{tabular}{|c|c|c|c|c|c|c|c|}
\hline Bağımlı Değişken & Bağımsız Değişken & B & $\mathbf{T}$ & $\mathbf{p}$ & $\mathbf{F}$ & Model (p) & $\mathbf{R}^{2}$ \\
\hline \multirow{2}{*}{$\begin{array}{c}\text { Madde Kullanma } \\
\text { Eğilimi }\end{array}$} & Sabit & 15,545 & 41,638 & 0,000 & \multirow{2}{*}{43,492} & \multirow{2}{*}{0,000} & \multirow{2}{*}{0,092} \\
\hline & Umutsuzluk & 0,314 & 6,595 & 0,000 & & & \\
\hline \multirow{4}{*}{$\begin{array}{l}\text { Madde Kullanma } \\
\text { Eğilimi }\end{array}$} & Sabit & 15,217 & 40,775 & 0,000 & \multirow{4}{*}{27,460} & \multirow{4}{*}{0,000} & \multirow{4}{*}{0,159} \\
\hline & Gelecekle İlgili Duygular & 0,270 & 1,898 & 0,058 & & & \\
\hline & Motivasyon Kayb1 & 0,954 & 7,604 & 0,000 & & & \\
\hline & GelecekleIllgili Beklentiler & $-0,311$ & $-1,929$ & 0,054 & & & \\
\hline
\end{tabular}

Umutsuzluk ile madde kullanma eğilimi arasındaki neden sonuç ilişkisini belirlemek üzere yapılan regresyon analizi anlamlı bulunmuştur $(\mathrm{F}=43,492 ; \mathrm{p}=0,000<0.05)$. Madde kullanma eğilimi düzeyindeki 
toplam değişim \%9.2 oranında umutsuzluk tarafından açılanmaktadır $\left(\mathrm{R}^{2}=0,092\right)$. Umutsuzluğun madde kullanma eğilimi düzeyini arttırdığı düşünülmektedir $(\beta=0,314)$.

Gelecekle ilgili duygular, motivasyon kaybı, gelecekle ilgili beklentiler ile madde kullanma eğilimi arasındaki neden sonuç iliş̧kisini belirlemek üzere yapılan regresyon analizi anlamlı bulunmuştur $(\mathrm{F}=27,460 ; \mathrm{p}=0,000<0.05)$. Madde kullanma eğilimi düzeyindeki toplam değişim $\% 15.9$ oranında gelecekle ilgili duygular, motivasyon kaybı, gelecekle ilgili beklentiler tarafından açıklanmaktadır $\left(\mathrm{R}^{2}=0,159\right)$. Gelecekle ilgili duyguların madde kullanma eğilimi düzeyini etkilemediği $(\mathrm{p}=0.058>0.05)$, motivasyon kaybının madde kullanma eğilimi düzeyini arttırdığ $(\beta=0,954)$, gelecekle ilgili beklentilerin madde kullanma eğilimi düzeyini etkilemediği düşünülmektedir $(\mathrm{p}=0.054>0.05)$.

Tablo 7. Madde Kullanma Eğiliminin Tanımlayıcı Özelliklere Göre Farklılaşma Durumu

\section{Demografik Özellikler}

\begin{tabular}{|c|c|c|}
\hline Cinsiyet & & Ort \pm SS \\
\hline Kadın & 220 & $19,209 \pm 4,123$ \\
\hline Erkek & 202 & $15,955 \pm 3,506$ \\
\hline$t=$ & & 8,695 \\
\hline $\mathrm{p}=$ & & 0,000 \\
\hline Yaș & & Ort \pm SS \\
\hline $18-24$ & 345 & $17,548 \pm 4,221$ \\
\hline 25 ve Üzeri & 77 & $18,117 \pm 3,903$ \\
\hline$t=$ & & $-1,084$ \\
\hline $\mathrm{p}=$ & & 0,279 \\
\hline Medeni Durum & & Ort \pm SS \\
\hline Evli & 33 & $17,424 \pm 4,184$ \\
\hline Bekar & 389 & $17,671 \pm 4,170$ \\
\hline $\mathrm{t}=$ & & $-0,326$ \\
\hline $\mathrm{p}=$ & & 0,744 \\
\hline Bölüm & & Ort \pm SS \\
\hline Beden Eğitimi ve Spor Öğretmenliği & 115 & $17,444 \pm 4,201$ \\
\hline Spor Yöneticiliği & 31 & $16,645 \pm 2,497$ \\
\hline Antrenörlük Eğitimi & 109 & $17,651 \pm 3,797$ \\
\hline Rekreasyon & 167 & $17,982 \pm 4,590$ \\
\hline $\mathrm{F}=$ & & 1,049 \\
\hline $\mathrm{p}=$ & & 0,371 \\
\hline Ortalama Gelir & & Ort \pm SS \\
\hline 500 Ve Alt1 & 102 & $17,020 \pm 3,907$ \\
\hline $501-1000$ & 155 & $17,729 \pm 4,461$ \\
\hline $1001-1500$ & 44 & $19,023 \pm 3,688$ \\
\hline $1501-2000$ & 40 & $17,475 \pm 3,863$ \\
\hline 2001 ve Üzeri & 81 & $17,642 \pm 4,196$ \\
\hline $\mathrm{F}=$ & & 1,824 \\
\hline $\mathrm{p}=$ & & 0,123 \\
\hline Sinif & & Ort \pm SS \\
\hline 1 & 109 & $18,220 \pm 4,315$ \\
\hline 2 & 73 & $18,027 \pm 3,325$ \\
\hline 3 & 144 & $17,542 \pm 4,244$ \\
\hline 4 & 96 & $16,885 \pm 4,379$ \\
\hline
\end{tabular}




\begin{tabular}{ll|}
\hline $\mathrm{F}=$ & 2,005 \\
\hline $\mathrm{p}=$ & 0,113 \\
\hline
\end{tabular}

Katılımcılardaki cinsiyet değişkenine bakıldığında, kadınların madde kullanma eğilimi puanları $(x=19,209)$, erkeklerin madde kullanma eğilimi puanlarından $(x=15,955)$ yüksek bulunmuştur $(t=8,695$; $\mathrm{p}=0<0.05$ ). Öğrencilerin madde kullanma eğilimi puanları yaş değişkenine, medeni durum değişkenine, bölüm değişkenine, ortalama gelir değişkenine ve sınıf değişkenine göre ise anlamlı farklılık göstermemektedir $(\mathrm{p}>0.05)$.

Tablo 8. Yaşam Doyumunun Tanımlayıcı Özelliklere Göre Farklılaşma Durumu

\section{Demografik Özellikler}

\begin{tabular}{|c|c|c|}
\hline Cinsivet & & Ort \pm SS \\
\hline Kadın & 220 & $20,841 \pm 5,995$ \\
\hline Erkek & 202 & $21,361 \pm 7,591$ \\
\hline$t=$ & & $-0,785$ \\
\hline $\mathrm{p}=$ & & 0,438 \\
\hline Yas & & Ort \pm SS \\
\hline $18-24$ & 345 & $21,148 \pm 6,625$ \\
\hline 25 ve Üzeri & 77 & $20,831 \pm 7,591$ \\
\hline$t=$ & & 0,369 \\
\hline$p=$ & & 0,736 \\
\hline Medeni Durum & & Ort \pm SS \\
\hline Evli & 33 & $20,788 \pm 8,358$ \\
\hline Bekar & 389 & $21,116 \pm 6,667$ \\
\hline $\mathrm{t}=$ & & $-0,265$ \\
\hline$p=$ & & 0,828 \\
\hline Bölüm & & Ort \pm SS \\
\hline Beden Eğitimi ve Spor Öğretmenliği & 115 & $21,409 \pm 7,218$ \\
\hline Spor Yöneticiliği & 31 & $21,387 \pm 7,753$ \\
\hline Antrenörlük Eğitimi & 109 & $20,954 \pm 7,008$ \\
\hline Rekreasyon & 167 & $20,904 \pm 6,215$ \\
\hline $\mathrm{F}=$ & & 0,159 \\
\hline$p=$ & & 0,924 \\
\hline Ortalama Gelir & & Ort \pm SS \\
\hline $500 \mathrm{Ve}$ Alt1 & 102 & $19,598 \pm 7,060$ \\
\hline $501-1000$ & 155 & $20,710 \pm 6,799$ \\
\hline $1001-1500$ & 44 & $22,818 \pm 4,144$ \\
\hline $1501-2000$ & 40 & $22,925 \pm 6,619$ \\
\hline 2001 ve Üzeri & 81 & $21,852 \pm 7,349$ \\
\hline $\mathrm{F}=$ & & 3,100 \\
\hline $\mathrm{p}=$ & & 0,016 \\
\hline PostHoc $=$ & & $3>1,4>1$, \\
\hline Sinıf & & Ort \pm SS \\
\hline 1 & 109 & $22,156 \pm 6,092$ \\
\hline 2 & 73 & $18,918 \pm 7,529$ \\
\hline 3 & 144 & $21,583 \pm 6,423$ \\
\hline 4 & 96 & $20,792 \pm 7,242$ \\
\hline $\mathrm{F}=$ & & 3,760 \\
\hline $\mathrm{p}=$ & & 0,011 \\
\hline PostHoc $=$ & & $1>2,3>2$ \\
\hline
\end{tabular}

Öğrencilerin yaşam doyumu puanları cinsiyet değişkenine, yaş değişkenine, medeni durum değişkenine ve bölüm değişkenine göre anlamlı farklılık göstermemektedir( $(\mathrm{p}>0.05)$. Öğrencilerin yaşam doyumu puanları, ortalama gelir değişkenine göre anlamlı farklılık göstermektedir $(F=3,100 ; p=0.016<0.05)$. Öğrencilerin yaşam doyumu puanları sınıf değişkenine göre anlamlı farklılık göstermektedir ( $\mathrm{F}=3,760$; $\mathrm{p}=0.011<0.05)$. 
Tablo 9. Umutsuzluğun Tanımlayıcı Özelliklere Göre Farklılaşma Durumu

\begin{tabular}{|c|c|c|c|c|c|}
\hline $\begin{array}{c}\text { Demografik } \\
\text { Özellikler }\end{array}$ & $\mathbf{n}$ & Umutsuzluk & $\begin{array}{l}\text { Gelecekle İlgili } \\
\text { Duygular }\end{array}$ & $\begin{array}{c}\text { Motivasyon } \\
\text { Kaybi }\end{array}$ & $\begin{array}{l}\text { Gelecekle İlgili } \\
\text { Beklentiler }\end{array}$ \\
\hline Cinsiyet & & Ort \pm SS & Ort \pm SS & Ort \pm SS & Ort \pm SS \\
\hline Kadın & 220 & $7,018 \pm 3,997$ & $1,350 \pm 1,487$ & $3,055 \pm 1,743$ & $2,109 \pm 1,429$ \\
\hline Erkek & 202 & $6,386 \pm 4,131$ & $1,203 \pm 1,530$ & $2,629 \pm 1,805$ & $1,951 \pm 1,438$ \\
\hline$t=$ & & 1,597 & 1,001 & 2,464 & 1,135 \\
\hline $\mathrm{p}=$ & & 0,111 & 0,318 & 0,014 & 0,257 \\
\hline Yaş & & Ort \pm SS & Ort \pm SS & Ort $\pm \mathrm{SS}$ & Ort \pm SS \\
\hline $18-24$ & 345 & $6,794 \pm 4,023$ & $1,290 \pm 1,491$ & $2,910 \pm 1,744$ & $2,038 \pm 1,431$ \\
\hline 25 ve Üzeri & 77 & $6,364 \pm 4,276$ & $1,234 \pm 1,589$ & $2,584 \pm 1,942$ & $2,013 \pm 1,455$ \\
\hline$t=$ & & 0,839 & 0,295 & 1,451 & 0,136 \\
\hline $\mathrm{p}=$ & & 0,402 & 0,768 & 0,148 & 0,892 \\
\hline Medeni Durum & & Ort \pm SS & Ort \pm SS & Ort \pm SS & Ort \pm SS \\
\hline Evli & 33 & $6,939 \pm 3,708$ & $1,242 \pm 1,601$ & $2,939 \pm 1,836$ & $2,091 \pm 1,208$ \\
\hline Bekar & 389 & $6,697 \pm 4,102$ & $1,283 \pm 1,502$ & $2,843 \pm 1,782$ & $2,028 \pm 1,453$ \\
\hline $\mathrm{t}=$ & & 0,329 & $-0,147$ & 0,297 & 0,241 \\
\hline $\mathrm{p}=$ & & 0,743 & 0,883 & 0,767 & 0,810 \\
\hline Bölüm & & Ort \pm SS & Ort \pm SS & Ort \pm SS & Ort \pm SS \\
\hline Beden Eğitimi ve & 115 & $7,470 \pm 4,404$ & $1,548 \pm 1,585$ & $3,017 \pm 1,924$ & $2,287 \pm 1,479$ \\
\hline Spor Yöneticiliği & 31 & $6,194 \pm 2,892$ & $1,161 \pm 1,440$ & $2,323 \pm 1,301$ & $2,000 \pm 1,483$ \\
\hline Antrenörlük & 109 & $5,927 \pm 4,104$ & $1,101 \pm 1,521$ & $2,551 \pm 1,798$ & $1,789 \pm 1,395$ \\
\hline Rekreasyon & 167 & $6,808 \pm 3,916$ & $1,234 \pm 1,444$ & $3,030 \pm 1,720$ & $2,024 \pm 1,401$ \\
\hline $\mathrm{F}=$ & & 2,921 & 1,850 & 2,870 & 2,283 \\
\hline $\mathrm{p}=$ & & 0,034 & 0,137 & 0,036 & 0,078 \\
\hline PostHoc $=$ & & $1>3(\mathrm{p}<0.05)$ & & $4>2,1>3,4>3$ & \\
\hline Ortalama Gelir & & Ort \pm SS & Ort \pm SS & Ort \pm SS & Ort \pm SS \\
\hline 500 ve Alt1 & 102 & $6,451 \pm 3,937$ & $1,226 \pm 1,495$ & $2,853 \pm 1,714$ & $1,863 \pm 1,586$ \\
\hline 501-1000 & 155 & $7,548 \pm 4,015$ & $1,587 \pm 1,537$ & $3,007 \pm 1,822$ & $2,297 \pm 1,290$ \\
\hline $1001-1500$ & 44 & $6,864 \pm 3,974$ & $1,091 \pm 1,344$ & $3,182 \pm 1,821$ & $2,205 \pm 1,456$ \\
\hline $1501-2000$ & 40 & $4,650 \pm 2,741$ & $0,650 \pm 1,252$ & $2,175 \pm 1,174$ & $1,450 \pm 1,218$ \\
\hline 2001 ve Üzeri & 81 & $6,395 \pm 4,549$ & $1,173 \pm 1,564$ & $2,704 \pm 1,959$ & $1,938 \pm 1,486$ \\
\hline $\mathrm{F}=$ & & 4,601 & 3,758 & 2,274 & 3,660 \\
\hline $\mathrm{p}=$ & & 0,001 & 0,005 & 0,061 & 0,006 \\
\hline PostHoc $=$ & & $2>1,1>4,2>4$ & $1>4,2>4,2>5$ & & $2>1,2>4,3>4$ \\
\hline Sinıf & & Ort \pm SS & Ort \pm SS & Ort \pm SS & Ort \pm SS \\
\hline 1 & 109 & $6,055 \pm 3,548$ & $0,982 \pm 1,155$ & $2,936 \pm 1,646$ & $1,734 \pm 1,317$ \\
\hline 2 & 73 & $7,493 \pm 3,816$ & $1,671 \pm 1,616$ & $2,699 \pm 1,639$ & $2,329 \pm 1,564$ \\
\hline 3 & 144 & $6,944 \pm 4,529$ & $1,417 \pm 1,679$ & $2,917 \pm 1,941$ & $2,104 \pm 1,447$ \\
\hline 4 & 96 & $6,531 \pm 4,008$ & $1,115 \pm 1,435$ & $2,771 \pm 1,809$ & $2,042 \pm 1,399$ \\
\hline $\mathrm{F}=$ & & 2,080 & 3,921 & 0,388 & 2,770 \\
\hline $\mathrm{p}=$ & & 0,102 & 0,009 & 0,762 & 0,041 \\
\hline PostHoc $=$ & & & $2>1,3>1,2>4$ & & $2>1,3>1$ \\
\hline
\end{tabular}

Kadınların motivasyon kaybı puanları $(x=3,055)$, erkeklerin motivasyon kaybı puanlarından $(x=2,629)$ yüksek bulunmuştur. Öğrencilerin umutsuzluk, gelecekle ilgili duygular, gelecekle ilgili beklentiler puanları cinsiyet değişkenine, yaş değişkenine, medeni durum değişkenine göre anlamlı farklılık 
göstermemektedir. Öğrencilerin umutsuzluk puanları, bölüm değişkenine göre anlamlı farkl1l1k göstermektedir. Öğrencilerin motivasyon kayb1 puanları bölüm değişkenine göre anlamlı farklılık göstermektedir. Öğrencilerin gelecekle ilgili duygular, gelecekle ilgili beklentiler puanları bölüm değişkenine göre anlamlı farklılık göstermemektedir.

Öğrencilerin umutsuzluk puanları ortalama gelir değişkenine göre anlamlı farklılık göstermektedir. Öğrencilerin gelecekle ilgili duygular puanları ortalama gelir değişkenine göre anlamlı farklılık göstermektedir. Öğrencilerin gelecekle ilgili beklentiler puanları ortalama gelir değişkenine göre anlamlı farklılık göstermektedir. Öğrencilerin motivasyon kaybı puanları ortalama gelir değişkenine göre anlamlı farkl111k göstermemektedir.

Öğrencilerin gelecekle ilgili duygular puanları sınıf değişkenine göre anlamlı farklılık göstermektedir. Öğrencilerin gelecekle ilgili beklentiler puanları sınıf değişkenine göre anlamlı farklılık göstermektedir. Öğrencilerin umutsuzluk, motivasyon kaybı puanları sınıf değişkenine göre anlamlı farklılık göstermemektedir.

\section{TARTIŞMA VE SONUÇ}

Çalışmamız sonucunda, örneklem grubumuzun "madde kullanma eğilimi” ortalaması 17,652 $\pm 4,166$ (Min=8; Maks=28) olarak saptanmıştır. Bu sonuca göre, örneklem grubumuzda bulunan öğrencilerin, genel olarak madde kullanma eğilimine sahip olduğu düşünülmektedir. Bunun birçok farklı sebebi olabilir. Ergen ve erişkin sporcuların alkol ve madde kullanımı ile ilgili yapılan çalışmalarda genel olarak sporun alkol ve madde kullanımına negatif etkisinden söz edilirken, belli spor dallarında kullanım oranının arttığı bildirilmiştir. Sporcuların kaygı ve ağrı düzeyini azaltmak, toplumsallaşmayı artırmak, yaralanmaların iyileşmesini hızlandırmak ve performanslarını yükseltmek amacıyla alkol ve madde kullanımına başvurdukları saptanmıştır (Karakaya, Coşkun ve Ağaoğlu, 2006). Genç nüfusta eğilimin yüksek olduğu göz önüne alınırsa, üzerinde çalıştığımız grubun spor bilimleri fakültesi öğrencileri olmas1 eğilimin yüksek olma sebeplerinden biri olarak düşünülebilir.

Uyuşturucu ve alkol kullanımının üniversite kampüslerinde yaygın bir sorundur ve öğrenci sporcuların, sporcu olmayan akranlarına kıyasla daha yüksek oranlarda tükettikleri varsayılmaktadır (Brisola-Santos ve ark., 2016). Paretti ve arkadaşları (2019) Fransız spor bilimleri öğrencileri üzerine yapılan bir çalışmada, farklı spor branşlarıyla uğraşan grupların esrar kullanımı için artan risk altında olduğu sonucuna varmışlardır. Spora katılım ve madde kullanımı arasındaki ilişki kullanılan maddeye göre değişiklik göstermektedir. Beklendiği gibi, hem sigara içimi hem de yasadışı uyuşturucu kullanımının spor katılımı ile ters ilişkili olduğu belirlenmiştir. Ancak, spora katılım ile alkol tüketimi arasında genellikle pozitif bir ilişki tespit edilmiştir. Gerçekten de, alkol üzerine yapılan 29 çalışmanın 22'si, alkol içmenin spor katılımı ile olumlu ilişkili olduğunu bulmuştur (Lisha ve Sussman, 2010).

Her ne kadar çalışma grubumuzdaki öğrencilerin madde kullanma eğilimine sahip oldukları belirlenmiş olsa da, yasadışı uyuşturucu kullanımını inceleyen 16 çalışmanın dokuzu, spora katılım ile madde kullanımı arasında negatif bir ilişki bulmuştur. Spora katılımın yasa dışı uyuşturucu kullanımına karşı koruyucu olduğu görülmektedir (Sussman et al., 2007). Buradan yola çıkarak eğilim olsa dahi spora katılım bir çeşit önlem olarak değerlendirilebilir.

Katılımcılardaki cinsiyet değişkenine bakıldığında kadınların madde kullanma eğilimi puanları, erkeklerin madde kullanma eğilimi puanlarından yüksek bulunmuştur. Türkiye'deki çalışmalar incelendiğinde, Sivas ilinde yapılan bir çalışmada uçucu madde kullanma oranının kadınlarda \%16.3, erkeklerde \%9.3, esrar kullanma oranının kadınlarda \%1.6, erkeklerde \%2.1 olarak belirlenmiştir (Doğan, 2001). Buğdaycı ve arkadaşları (2003) tarafindan yapılan çalışmada alkol içme oranının erkeklerde \%54.1, kadınlarda \%34.1 olduğu; Tot ve arkadaşları (2004) tarafından yapılmış çalışmada bu oranın erkeklerde \%53.8 kadınlarda \%33 olduğu; Şaşmaz ve arkadaşlarının (2006) çalışmasında erkeklerin \%27.6'sının kadınların \%20.9'unun yaşamları boyunca en az bir kez alkol denemesi gerçekleştirdikleri, aynı çalışmada erkeklerin \%12.3'ü kadınların ise \%4'ünün son 30 günde alkol kullandığı sonucu belirtilmiştir. 
Herken, Bodur ve Kara'nın (2000) çalışmalarının sonucunda, üniversite öğrencisi kızlarda sigara kullanımının kişilik özellikleri ile ilişkisi olmakla birlikte daha çok sosyal ilişkilerle, alkol ve ilaç kullanımının ise sosyal ilişkilerden çok ruhsal durum ve kişilik özellikleri ile ilişkili olduğu söylenebilir. Beş üniversitenin öğrencilerinden veri toplanarak gerçekleştirilen ve üniversite öğrencilerinde içme davranışının yaygınlığını çeşitli sosyo demografik değişkenler açısından inceleyen bir araştırmada (İlhan, Yıldırım, Demirbaş ve Doğan, 2008), alkol kullanım yaygınlığının \% 9,2 olduğu bulunmuştur. Ayrıca, erkeklerde, kentte yaşayanlarda, ailesiyle ya da arkadaşlarıyla yaşayanlarda, aylık geliri orta ve iyi olanlarda, akademik performansını orta ve iyi olarak değerlendirenlerde alkol kullanımının daha yaygın olduğu gözlenmiştir. Ülkemizde üniversiteli gençler arasında alkol ve madde kullanım yaygınlığının düşük düzeyde olması memnuniyet vericidir. Kullanım yaygınlığını belirlemeye yönelik gerçekleştirilen araştırmalar bulunmaktadır (Kızıltaş, 2019).

Öğrencilerin madde kullanma eğilimi puanları yaş, medeni durum, bölüm, ortalama gelir ve sınıf değișkenine göre ise anlamlı farklılık göstermemektedir. Her ne kadar gelir durumuna göre farkl1lık görülmese de, birçok çalışmada bu durumun aksi görülmekte ve madde kullanma eğilimi ile düşük gelir arasında bir ilişki olduğu belirlenmiştir. Ancak, özellikle sporcu kimliği olan kadınlarda madde kullanma eğilimi ile ilgili yeterli seviyede çalışma bulunmamaktadır. Bu tarz çalışmaların yapılmasının literatüre katkı sağlaması açısından faydalı olacağı düşünülmektedir.

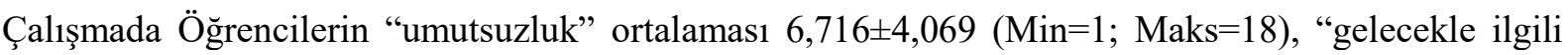

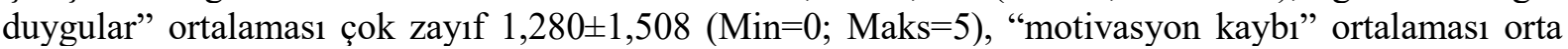
2,851 $\pm 1,784$ (Min=0; Maks=8), "gelecekle ilgili beklentiler" ortalamas1 zayıf 2,033 $\pm 1,434$ (Min=0; Maks=5), olarak saptanmıştır. Araştırmada kullanılan umutsuzluk ölçeğinde gelecekle ilgili duygular, motivasyon kaybı ve gelecekle ilgili beklentiler olmak üzere üç boyut bulunmaktadır. Bu boyutlardan gelecekle ilgili duygular ve gelecekle ilgili beklentiler boyutlarına yönelik umutsuzluğun madde kullanım eğilimi üzerinde etkisinin olmadığı, motivasyon kaybının ve genel umutsuzluk düzeyinin ise madde kullanım eğilimini artırdığı saptanmıştır.

Tümkaya ve arkadaşları (2007) tarafindan yapılan çalışmada, üniversite öğrencilerindeki umutsuzluğun yükselmesi gelişmekte olan bir ülke olan Türkiye'de üniversiteli işsizlerin çokluğuna bağlanmıştır. Yine, D'Zurilla, ve arkadaşlarına (1998) göre de iş bulamama korkusu ve ekonomik kaygılar bireylerin umutsuzluk düzeylerini artırmaktadır. Çalışmamızda Gelecekle ilgili beklentiler ile yaşam doyumu arasında $\mathrm{r}=-0.257$ negatif yönlü ilişki olduğu saptanmıştır. Dost (2007) tarafindan üniversite öğrencilerinin yaşam doyumlarını belirlemeye yönelik yapılan araştırmada da ise üniversite öğrencilerinin yaşam doyumlarının geleceğe ilişkin beklentileri ile ilişkili olduğu ve geleceğe daha iyimser bakan öğrencilerin yaşam doyumlarının daha yüksek olduğu bulunmuştur. Bir diğer çalışmada öğrencilerin umutsuzluk ve yaşam doyumları arasında ise orta seviyede negatif bir ilişki olduğu belirlenmiştir. Buna göre, öğrencilerin umutsuzlukları arttıkça yaşam doyumları azalmaktadır. Öğrencilerin umutsuzluk içinde bulunmaları yaşam doyumlarını olumsuz şekilde etkilediği düşünülmektedir (Gençay, 2009).

Shin ve Johnson (1978)'e göre yaşam doyumu, genel olarak bireyin hayatının kalitesini kendisinin belirlemiş olduğu kriterlere göre değerlendirmesidir. Yaşam doyumu, bir bütün olarak yaşamın bütün kalitesinin pozitif gelişiminin derecesi olarak tanımlanabilir (Veenhoven, 1996). Çalışmamız sonucunda katılımcıların "yaşam doyumu" ortalaması 21,090土6,803 (Min=5; Maks=35) olarak saptanmıştır. Çalışma grubumuzdaki Spor Bilimleri Fakültesi öğrencilerin genel yaşam doyumları orta düzeydedir. Madde kullanma eğilimi ile yaşam doyumu arasındaki ilişki incelendiğinde, madde kullanma eğilimi düzeyindeki toplam değişim \%1.9 oranında yaşam doyumu tarafından açıklanmaktadır $\left(R^{2}=0,019\right)$. Yaşam doyumunun madde kullanma eğilimi düzeyini azalttığı düşünülmektedir. Literatürde yaşam doyumunun madde kullanma eğilimi üzerindeki etkilerine ilişkin çalışma azlığı bulunmaktadır. Kulaksızoğlu vd. (2009) bireyin, yaşam olaylarına dair bilgiyi belirsizlik olarak algılar ve değerlendirme bilişsel, emosyonel ve davranışsal bir dizi tepkiyle yanıta dönüştügünü belirtmektedir. Wicks-Nelson ve Israel (2003), ergenlerin, madde ve alkol kullanımını stresle başa çıkmada bir yol olarak kullandıklarını, yüksek oranda olumsuz yaşam olayları ve stres algılayan ergenlerin, madde ve alkol kullanmalarının daha olası olduğunu bildirmişlerdir. Newcomb ve Harlow (1986) daha fazla olumsuz yaşam durumlarına 
ve günlük sorunlara maruz kalan gençler arasında, alkol ve madde kullanımının fazla olduğunu öne sürmüşlerdir. İlhan (2009)'ın yaptı̆̆ araştırmada, öznel iyi oluşun alkol kulanım sıklığı ile olumsuz yönde fakat bu ilişkinin anlamsız düzeyde olduğu yönündedir. Düşük düzeyde yaşam doyumu ise alkol ve zararlı madde kullanımı, depresyon, kaygı ve stres ile ilişkilendirilmektedir (Gilman ve Huebner, 2003). Buna ek olarak, ilerleyen yıllarda da yüksek düzeyde yaşam doyumu bildiren çocukların daha az dışa yönelim sorunları gösterdikleri vurgulanmaktadır (Huebner, 2004). Cautin, Overholser ve Goetz (2001) tarafından yapılan bir araştırmada öfkenin içe ya da dı̧̧a yöneltilmesi ve öfke biçimi ile ilişkili psikolojik sorunlar incelenmiş olup dişa yönelik öfke düzeyleri yüksek olan bireylerin, düşük olan bireylere göre bağımlılıkla ilişkili sorunlarının daha fazla olduğu bulunmuştur. İlhan (2013), madde kullanan üniversite öğrencilerinin kullanmayanlara göre, yaşam amaçlarının daha düşük olduğunu raporlamıştır. Alana ait bir araştırmada, yaşam amaçları eksik olan bireylerin bu eksikliği madde kullanarak gidermeye çalıştı̆̆ sonucuna ulaşılmıştır (Kasser ve Ryan, 1996; İlhan, 2013). Araştırmada yaşam doyumunun madde kullanma eğilimini azalttığına ilişkin elde edilen sonuç, kuramsal bilgiyi desteklemektedir.

Sonuç olarak; spor bilimleri fakültesi öğrencilerinde, umutsuzluğun ve düşük yaşam doyumunun madde kullanma eğilimini arttırdığı, madde kullanma eğiliminin kadın öğrencilerde, erkek öğrencilere göre yüksek olduğu, madde kullanma eğiliminin yaş, medeni durum, bölüm, ortalama gelir ve sınıf durumundan etkilenmediği belirlenmiştir.

Bilgilendirme / Acknowledgement: Bu çalışma 21.01.2020 tarihinde Muğla Sttkı Koçman Üniversitesi Sağlık Bilimleri Enstitüsünce kabul edilen yüksek lisans tezinden türetilmiştir.

\section{KAYNAKÇA}

Akyüz, B.Ü. (2014). Kadınların kariyer engelleri ile kariyer tatmini ve yaşam doyumu ilişsisi. Yayımlanmamış yüksek lisans tezi, Mehmet Akif Ersoy Üniversitesi Sosyal Bilimleri Enstitüsü, Burdur.

Aşan, Ö. ve Erenler, E. (2008). İş tatmini ve yaşam tatmini ilişkisi. Süleyman Demirel Üniversitesi İktisadi ve İdari Bilimler Fakültesi Dergisi, 13(2), 203-216

Beyazyürek, M. ve Şatır, T. T. (2000). Madde kullanım bozuklukları. Psikiyatri Dünyası, 4(2), 50-56

Brisola-Santos, M.B., Gallinaro, J.G., Gil, F., Sampaio-Junior, B. Marin, M.C.D. de Andrade, A.G. RichteR, K.P, Glick I.D.Baltieri, D.A. ve Castaldelli-Maia, J.M.(2016). Prevalence and correlates of cannabis use among athletes-A systematic review. The American Journal on Addictions, 25(7), 518-528.

Buğdaycı, R., Şaşmaz, T., Aytaç, N. ve Çamdeviren, H. (2003). Mersin, Adana ve Hatay illerinde beden eğitimi ve spor yüksek okulu öğrencilerinde alkol içme prevalansı ve etkileyen faktörler. Turkiye Klinikleri J Med Sci, 23, 208-12.

Cautin, R.L., Overholser, J.C. ve Goetz, P. (2001). Assessment of mode of anger expression in adolescent psychiatric inpatients. Adolescence, 36, 163-70

Ceyhun, B. ve Oral, N. (2003). Minnesota çok yönlü kişilik envanteri değerlendirme kitabı. 2. Baskı. Ankara: Çizgi Tıp Yayınevi.

D’Zurilla, T.J., Chang, E.C., Nottingham, E.J. ve Faccini, L. (1998). Social problem solving deficits and hopelessness, depression and suicidal risk in college students and psychiatric impatients. Journal of Clinic Psychology, 54, 1091-1107

Dalack, G.W., Glasman, A.H. ve Cavey L.S. (1993). Nicotin use, current psychiatric therapy, L Dunner (Ed), Philadelphia, WB Saunders Company. 
Diener, E., Oishi, S. ve Lucas, R. E. (2003). Personality, culture, and subjective well-being: Emotional and cognitive evaluations of life. Annu.Rev.Psychol., 54, 403-25

Dilbaz, N. ve Seber, G. (1993). Umutsuzluk kavramı: Depresyon ve intiharda önemi. Kriz Dergisi, 1(3), $134-138$

Doğan, O. (2001). Sivas ilindeki lise öğrencilerinde madde kullanım yaygınlığı. Bağımlılık Dergisi, 2, $53-56$.

Dolu, O. (2010). Suç teorileri: Teori, araştırma ve uygulamada kriminoloji. Ankara: Seçkin Yayıncılık.

Dost, T.M. (2007). Üniversite öğrencilerinin yaşam doyumlarının bazı değişkenlere göre incelenmesi. Pamukkale Üniversitesi Eğitim Fakültesi Dergisi, 22, 132-142.

Eroğlu, E. (2011). Örgütlerde iletişim kalitesini etkileyen faktörlerin değerlendirilmesi. Selçuk Üniversitesi Sosyal Bilimler Enstitüsü Dergisi, (26), 137-149

Gençay, S. (2009). Beden eğitimi öğretmeni adaylarının umutsuzluk ve yaşam doyumlarının bazı değişkenler açısından incelenmesi. Elektronik Sosyal Bilimler Dergisi, 8(27), 380-388

Gilman, R. ve Huebner, E.S. (2003). A review of life satisfaction research with children and adolescents. School Psychology Quarterly, 18, 192-205

Gülkan, B.C. (1994). Eroin bağımlılarının kişsilik ve sosyodemografik özellikleri. Yayımlanmamış yüksek lisans tezi, İstanbul Üniversitesi Adli Tıp Enstitüsü, İstanbul.

Herken, H., Bodur, S. ve Kara, F. (2000). Üniversite öğrencisi kızlarda madde kullanımı ile kişilik ve ruhsal belirti ilişkisi. VII. Ulusal Eğitim Bilimleri Kongresi, Konya.

Huebner, E.S. (2004). Research on assessment of life satisfaction of children and adolescents. Social Indicators Research, 66, 3-33.

İlhan, İ.Ö., Yıldırım, F., Demirbaş, H. ve Doğan, Y.B. (2008). Alcohol use prevalence and sociodemographic correlates of alcohol use in a university student sample in Turkey. Social Psychiatry and Psychiatric Epidemiology, 43(7), 575-583.

İlhan, T. (2009). Üniversite ögrencilerinin yaşam amaçları ve madde kullanımı. XVIII. Ulusal Eğitim Bilimleri Kurultayı, Ege Üniversitesi, İzmir.

İlhan, T. (2013). Üniversite öğrencilerinde yaşam amaçları ve madde kullanımı. Uş̧ak Üniversitesi Sosyal Bilimler Dergisi, 6(2), 183-196.

Karakaya I., Coşkun A., ve Ağaoğlu B. (2006) yüzücülerin depresyon, benlik saygısı ve kaygı düzeylerinin değerlendirilmesi, Anadolu Psikiyatri Dergisi, 7, 162-166

Kızıltaş, A. (2019). Üniversite ögrrencilerinin öz denetim, stresle başa çıkma ve sosyal destek algıları ile alkol ve madde kullanma riskleri arasındaki ilişkilerin incelenmesi. Yayımlanmamış doktora tezi, Hacettepe Üniversitesi Sosyal Bilimler Enstitüsü Sosyal Hizmet Anabilim Dalı, Ankara.

Kulaksızoğlu, B.I., Tükel, R., Üçok, A., Yargıç, İ. ve Yazıcı, O. (2009). Psikiyatri. İstanbul: İstanbul Üniversitesi Basım ve Yayınevi.

Lisha, N.E., ve Sussman, S. (2010). Relationship of high school and college sports participation with alcohol, tobacco, and illicit drug use: A review. Addictive Behaviors, 35(5), 399-407.

Mc Laughlin, J., Miller, P. ve Warwick, H. (1996). Deliberate self-harm in adolescents: Hopelessness depression, problem sand problem-solving. Journal of Adolescence, 19(6), 523-532.

Newcomb, M.D. ve Harlow, L.L. (1986). Life events and substance use among adolescents. Journal of Personality and Social Psychology, 51(3), 564-577.

Pate, R.R., Trost, S.G., Levin, S. ve Dowda, M. (2000). Sports participation and health relatedbehaviors among US youth. Archives of Pediatrics and Adolescence Medicine, 154, 904-911. 
Peretti-Watel, P., Seror, V., Lorente, F., Doucende, G. ve Martha, C. (2019). Cannabis use and patterns of substance use among french sport sciences students. J. Addict. Addictv. Disord. 6, 20.

Plante, T.G. Rodin, J. (1990). Physical fitness and enhanced psychological health. Current Psychology Research and Review, 9, 3-24.

Rideout, E. ve Montemuro, M. (1986). Kronik kalp yetmezliği olan hastalarda umut, moral ve adaptasyon. İleri Hemşirelik Dergisi, 11(4), 429-438

Sasmaz, T., Buğdaycı, R. Toros, F. Öner Kurt, A., Tezcan, H., Öner, S. ve Camdeviren, H. (2006). Ergenlerde alkol icme prevelansi ve olasi risk faktörleri: Okul tabanli kesitsel bir çalisma. Preventive Medicine Bulletin, 5(2), 94-104.

Seligman, M.E.P. (2007). Gerçek mutluluk. Kalıcı doyum potansiyelinizi geliştirmek için yeni olumlu psikolojinin kullanılması. Ankara: HYB.

Shin, D.C. ve Johnson, D.M. (1978). Avowed happiness as an overall assessment of the quality of life, Social Indicators Research: An International and Interdisciplinary. Journal for Quality of-Life Measurement, 5(1), 475 - 492.

Sirgy, J.M., Michalos, A. C., Ferris, A., Easterlin, R., Patrick, D. ve Pavot, W. (2006). The quality-of-life (QoL) research movement: past, present, and future. Social Indicators Research, 76, 343-466.

Sussman, S., Pokhrel, P., Ashmore, R.D. ve Bradford B.B. (2007). Adolescent peer group identification and characteristics: a review of the literatüre. Addictive Behaviors, 32 ,1602-1627.

Tot, Ş., Yazıcı, A., Yazıcı, K., Erdem, P., Bal, N. ve Metin, Ö. (2004). Mersin'de ergenler arasında sigara,alkol ve yasa dışı madde kullanım oranlarının yaygınlığı: ortaokul, lise ve üniversite öğrencilerinin karşılaştırılması. New Symposium, 42,77-81.

Tümkaya, S., Aybek B. ve Çelik, M. (2007). A prediction of hopelessness and state-trait anxiety levels among teacher candidates before the KPSS exam. Educational Sciences: Theory \& Practice, 7(2), 967-974.

Türk Dil Kurumu. (2005). Türkçe sözlük (10. bask1). Ankara: TDK.

Üngüren, E. ve Ehtiyar, R. (2009). Türk ve alman öğrencilerin umutsuzluk düzeylerinin karşılaştırılması ve umutsuzluk düzeylerini etkileyen faktörlerin belirlenmesi: turizm eğitimi alanöğrenciler üzerinde bir araştırma. Journal of Yasar University, 4(14), 2093-2127.

Wade, C. ve Tavris, C. (1999). Invitation to psychology. US: Addison-Wesley Longman.

Wicks-Nelson, R. ve Israel, A.C. (2003). Behaviour disorders of childhood. New Jersey: Prentice Hall.

Yetim, U. (1993). Life satisfaction: A study based on the organization of personal projects. Social Indication Research, 29, 277-89. 